\title{
ANALISIS POLA INTERAKSI DALAM PEMBELAJARAN EKONOMI DI SEKOLAH MENENGAH ATAS KECAMATAN SINTANG KALIMANTAN BARAT
}

\author{
Yulia Suriyanti, STKIP Persada Khatulistiwa Sintang \\ yuliasuryanti@stkippersada.ac.id \\ Valentinus Ola Beding, STKIP Persada Khatulistiwa Sintang \\ valentinus.beding86@gmail.com
}

\begin{abstract}
ABSTRAK
Kecamatan Sintang merupakan salah satu wilayah timur Provinsi Kalimantan Barat yang masih mengalami banyak kendala dalam proses pembelajaran, salah satunya adalah rendahnya motivasi belajar siswa. Dengan demikian, tujuan dari penelitian ini adalah untuk mengetahui bagaimana gambaran pola interaksi dalam proses pembelajaran Ekonomi perspektif guru pengampu mata pelajaran Ekonomi serta siswa Sekolah Menengah Atas Di Kecamatan sintang yang terdiri dari 12 sekolah. Penelitian ini termasuk jenis kualitatif dengan bentuk survei serta disajikan dalam bentuk deskriptif. Metode pengumpulan data yang digunakan adalah wawancara, observasi dan dokumentasi serta angket untuk memperoleh informasi terkait pengalaman siswa dalam proses pembelajaran Ekonomi. Hasil penelitian yang diperoleh adalah bahwa metode pembelajaran yang biasa digunakan oleh guru Ekonomi SeKecamatan Sintang yaitu metode ceramah, tanya jawab dan diskusi kelompok dengan pola interaksi satu arah, dua arah, tiga arah dan pola interaksi banyak arah hanya ditemukan pada salah satu subjek penelitian. Sedangkan hasil angket siswa menunjukkan bahwa $80 \%$ siswa lebih menyukai apabila guru menggunakan metode pembelajaran yang lebih bervariasi dengan pola interaksi banyak arah.
\end{abstract}

Kata Kunci: Pola Interaksi, Pembelajaran Ekonomi.

\begin{abstract}
This study aimed at knowing how the description of interaction patterns in the Economic learning process through the Economic teachers' perspective subjects as well as high school students in District of Sintang which consisting of twelve schools. This research uses qualitative approach with survey form and presented in descriptive form. Data collection methods used were interviews, observation, documentation and questionnaires to obtain information related to student experience in Economic learning process. The result obtained from this research was that learning method commonly used by Economics teacher in Sintang Sub-district is lecture, question and answer method and group discussion with one way, two-way, three-way method, while many-way interaction pattern only found in one of the research subjects. While the student
\end{abstract}


questionnaire results showed that $80 \%$ of students prefer when theteacher uses a more varied learning method with many-way interaction patterns.

Keywords: Interaction Pattern, Economic Learning.

\section{PENDAHULUAN}

Kalimantan Barat merupakan salah satu provinsi di Indonesia yang masih tergolong provinsi dengan tingkat pendidikan rendah. Data BPS Provinsi Kalimantan Barat (2016) menunjukkan tingkat pendidikan masyarakat berada pada level Sekolah Menengah Pertama (SMP). Di sisi lain, Kepala Dinas Pendidikan Kalimantan Barat menyatakan bahwa permasalahan pokok pendidikan di Sintang adalah: 1) Keterbatasan akses pendidikan, 2) Rendahnya mutu, relevansi, dan daya saing luaran (out-put) pendidikan, dan 3) Tata kelola, pencitraan publik, dan akuntabilitas berbagai kegiatan yang ada di sekolah (Akim, 2010).

Terkait pernyataan tersebut, beberapa penelitian yang menunjukkan bagaimana proses pendidikan pada sekolah menengah di Kalimantan Barat dilaksanakan, yaitu penelitian oleh (Roza Lianti, 2016) yang menyatakan rendahnya kedisiplinan belajar pada siswa Sekolah Menengah Pertama (SMP) di salah satu sekolah negeri yang terdapat di Sintang. Hasil penelitian menunjukkan rendahnya kedisplinan siswa salah satunya disebabkan oleh penjelasan guru yang sulit dimengerti. Penelitian berikutnya oleh (Novi Irmawati, 2013) menunjukkan bahwa beberapa faktor yang dihadapi guru dalam meningkatkan konsentrasi belajar siswa di salah satu sekolah menengah atas (SMA) negeri di Sintang adalah rendahnya motivasi belajar siswa serta lingkungan sekolah yang kurang mendukung untuk proses pembelajaran yang kondusif. Penelitian laiannya oleh Julianto (Julianto, 2017) menyatakan bahwa siswa sekolah menengah atas (SMA) di Sintang mengalami tingkat kesulitan belajar mencapai 69,33\% dengan kategori tinggi. Hal tersebut dipengaruhi oleh faktor inteligensi 58,6\%, kondisi jasmani 51,1\% dan lingkungan $61,6 \%$.

Dari beberapa permasalahan di atas menunjukkan kesesuaian antara rendahnya level pendidikan di Sintang dengan faktor-faktor yang mempengaruhi. Kondisi yang sangat memprihatinkan dan berdampak pada rendahnya sumber daya manusia di kabupaten Sintang. Disisi lain pembangunan pada aspek pendidikan terus digaungkan yang kemudian seolah hanya menjadi buah mulut saja. Tidak dipungkiri bahwa penambahan jumlah gedung sekolah baik tingkat SD, SMP maupun SMA mencapai dua kali lipat pada tahun 2017. Akan tetapi kualitas pembelajaran masih juga berada pada level yang rendah. Hal tersebut menimbulkan pertanyaan, bagaimana kondisi ataupun proses pembelajaran di sekolah berlangsung.

Setiadi dan Kolip (2011) mengatakan bahwa "interaksi merupakan hubungan antarmanusia yang sifat dari hubungan tersebut adalah dinamis artinya hubungan itu tidak statis, selalu mengalami dinamika". Sedangkan, H. Booner (Gerungan W.A, 2010) memberikan rumusan interaksi sosial, bahwa interaksi sosial adalah hubungan antara dua individu atau lebih, dimana kelakuan individu yang satu mempengaruhi, mengubah, atau memperbaiki kelakuan individu lain atau sebaliknya. Interaksi sosial adalah hubungan- 
hubungan antara orang - orang secara individual. Antar kelompok orang, dan orang perorang dengan kelompok.

Dengan demikian, pola interaksi merupakan suatu cara, model, dan bentuk-bentuk interaksi yang saling memberikan pengaruh dan mempengaruhi dengan adanya timbal balik guna mencapi tujuan. Guru sebagai pengajar memiliki peran penting untuk dapat mengatur jalannya kegiatan belajar mengajar melalui pola interaksi dimana guru berperan sebagai pemberi aksi melalui pengajaran dan juga bisa menjadi penerima aksi melalui pertanyaanpertayaan yang diajukan oleh siswa. Sebaliknya siswa pun memiliki peran yang sama dengan guru bisa sebagai pemberi aksi melalui melalui pertanyaanpertayaan yang diajukan olehnya dan juga bisa menjadi menjadi penerima aksi melaui belajar dan mendengarkan. Namun, kerjasama dapat sangat membantu dalam proses kegiatan pembelajaran yang diperlukan oleh guru dan siswa.

Terdapat beberapa jenis pola interaksi dalam pembelajaran Ekonomi, yaitu: satu arah, dua arah, dan tiga arah atau banyak arah (Sumiati \& Asara, 2008). Pola interaksi satu arah merupakan bentuk komunikasi dimana guru sebagai pemegang kendali saaat proses pembelajaran berlangsung. Siswa hanya berperan sebagai pendengar. Pola interaksi dua arah merupakan pola komunikasi antara guru dan siswa. Akan tetapi masih belum melibatkan ruang dan kondisi kelas secara sepenuhnya. Siswa dan guru sudah dapat saling berdiskusi dan mengajukan pertanyaan antara satu dengan yang lain. Sedangkan pola interaksi tiga arah atau banyak arah merupakan bentuk komunikasi yang melibatkan kelas secara aktif. Siswa dan guru secara bersama-sama membangun suasana yang edukatif dan kooperatif. Siswa dapat saling berdiskusi dan membantu satu dengan yang lainnya selain komunikasi dengan guru. Dalam komunikasi banyak arah, guru juga dapat menggunakan berbagai macam metode dan model pembelajaran.

Berdasarkan uraian di atas, adapun tujuan dari penelitian ini adalah untuk menemukan gambaran dan merefleksikan temuan pola interaksi dalam pembelajaran Ekonomi di Sekolah Menengah Atas (SMA) Kecamatan Sintang, Kalimantan Barat serta menemukan faktor-faktor yang mempengaruhi pola interaksi tersebut sehingga dapat menjadi acuan penggunaan model ataupun metode pembelajaran yang tepat dalam proses pembelajaran ekonomi, kemudian dapat menjadi masukan semua pihak terkait pihak sekolah yang meliputi semua unsur yang terlibat dalam pembelajaran Ekonomi di sekolah.

\section{METODE PENELITIAN}

Penelitian ini termasuk dalam pendekatan kualitatif dengan bentuk penelitian survei dan disajikan dalam bentuk deskriptif dimana data yang sudah diperoleh digambarkan secara rinci sesuai dengan temuan yang ada di lapangan. Subjek dalam penelitian ini adalah guru dan siswa Sekolah Menengah Atas (SMA) di Kecamatan Sintang Provinsi Kalimantan Barat. Adapun jumlah guru yang menjadi subjek penelitian adalah 12 (dua belas) orang yang merupakan guru mata pelajaran Ekonomi. Sedangkan siswa yang menjadi subjek penelitian berjumlah 120 (seratus dua puluh) siswa yang dipilih secara purposive. Adapun kriteria pemilihan siswa sebagai subjek penelitian 
dengan pertimbangan yaitu: (1) masing-masing 10 (sepuluh) siswa dari setiap sekolah penelitian. (2) siswa yang bersangkutan menerima pelajaran Ekonomi dari guru yang juga merupakan subjek penelitian, (3) dari 10 (sepuluh) siswa dibagi kembali menjadi 3 (tiga) dengan kategori siswa dengan nilai Ekonomi baik, sedang dan kurang. Objek pada penelitian ini adalah aktivitas pembelajaran dengan pola interaksi yang dilakukan oleh guru pada pembelajaran Ekonomi.

Instrumen yang digunakan dalam penelitian ini adalah pedoman wawancara untuk mengetahui pola interaksi yang digunakan oleh guru dalam mengajar Ekonomi. Sedangkan pedoman observasi digunakan untuk menggali lebih dalam proses pembelajaran Ekonomi yang berlangsung di dalam kelas. Instrumen lain yang digunakan dalam penelitian ini adalah angket. Adapun angket digunakan untuk mengetahui perspektif siswa berkaitan dengan pola interaksi yang digunakan oleh guru ekonomi saat mengajar.

Analisis data penelitian ini secara deskriptif kualitatif dengan teknik analisis data model interaktif menurut (Miles \& Huberman, 2007) terdiri dari empat tahapan yang harus dilakukan oleh peneliti, yaitu pengumpulan data, reduksi data, display data, serta kesimpulan atau tahap verifikasi. Proses analisis data dilakukan secara simultan yang mencakup klarifikasi, interpretasi dan analisis data. Analisis data dilakukan secara deskriptif (descriptive analysis).

\section{HASIL PENELITIAN DAN PEMBAHASAN}

Guru Ekonomi SMA di 12 sekolah di Kecamatan Sintang sudah menggunakan berbagai macam metode dalam pembelajaran Ekonomi. Ratarata responden sudah menggunakan metode pembelajaran yang bervariasi. Hasil jawaban responden menunjukkan bahwa metode yang sering digunakan dalam pembelajaran Ekonomi adalah ceramah, tanya jawab dan diskusi kelompok. Akan tetapi, untuk responden 8 (delapan) sudah menyertakan permainan dalam pembelajaran selain metode ceramah, tanya jawab dan diskusi kelompok.

Adapun alasan menggunakan metode tersebut diatas, responden 1 (satu) menjawab "kalau ceramah ya sebagai pengantar, apakah siswa sudah mempelajari materi dirumah atau belum" ceramah hanya sebagai pengantar dalam proses pembelajaran Ekonomi. Responden 2 "karena kalau kita, ceramahkan berbicara. Kalau ceramahkan tradisional. Ada tanya jawabnya, ada diskusinya maka ceramah bervariasi." ceramah yang dilakukan tidak bersifat monoton akan tetapi bervariasi. Responden 3 dan 11 menyatakan alasan menggunakan metode tersebut dikatrenakan mudah untuk dilaksanakan dan adanya fasilitas yang menunjang. Responden 4, 5, 6, 7 dan 10 menyatankan penggunaan metode ceramah digunakan karena siswa belum mampu mandiri, kurang membaca dirumah dan keadaan sekolah yang minim fasilitas. Responden 8 menyatakan metode permainan sering digunakan dengan alasan siswa mengantuk pada siang hari, jadi jika menggunakan ceramah siswa akan semakin mengantuk. Responden 9 menyatakan metode diskusi dan tanya jawab digunakan agar terjadi interaksi Sedangkan responden 12 menyatakan 
penggunaan metode ceramah justru membantu siswa untuk aktif dan tidak tidur dikelas.

Menurut responden, metode yang sering digunakan tersebut tentunya memuliki kekurangan dan kelebihan. Seperti metode ceramah, semua responden sepakat menyatakan bahwa apabila ceramah saja yang digunakan akan mengakibatkan siswa bosan dan pembelajaran menjadi monoton. Selain itu metode ceramah. Meskipun demikian, metode ceramah juga memiliki beberapa kelebihan yaitu, dapat dikombinasikan dengan metode-metode lainnya, mudah dilaksanakan, meng-aktifkan siswa, selalu dapat disesuaikan dengan jam pelajaran, metode yang paling tepat untuk meng-cover keadaan.

Sedangkan metode diskusi dan tanya jawab menjadi metode pilihan responden dengan beberapa alasan, yaitu: "dapat mendeteksi pemahaman siswa karena apabila siswa bertanya menandakan siswa belajar" (responden 1, 2, dan 3). Responden lain berpendapat bahwa dengan adanya tanya jawab dan diskusi membantu siswa untuk dapat saling berinteraksi, baik interaksi guru dengan siswa maupun siswa dengan siswa. Kelebihan lainnya adalah dengan metode tanya jawab dan diskusi siswa "dipaksa" untuk belajar sendiri di rumah sehingga pada saat tanya jawab berlangsung siswa sudah memiliki cukup "modal" untuk berdiskusi atau menjawab pertanyaan-pertanyaan dari guru.

Menjawab pertanyaan terkait perbedaan metode yang digunakan dari satu kelas dengan kelas lainnya, 11 (sebelas) responden sebagai guru Ekonomi sepakat mengatakan bahwa ada perbedaan metode dan pola interaksi pada kelas yang berbeda. Sedangkan 1 (satu) responden menjawab sama.

Kemudian terkait faktor yang mempengaruhi pola interaksi antara guru dan siswa dalam proses pembelajaran, responden memiliki jawaban yang bervariasi. Responden 2, 9, 10, 11, dan 12 mengatakan bahwa guru dan siswa adalah faktor yang paling menentukan pola interaksi antara guru dan siswa dalam pembelajaran Ekonomi. Adapun yang dimaksud guru dan siswa adalah bahwa pembelajaran tidak dapat berlangsung apabila tanpa kesiapan dari siswa khususnya kesiapan fisik dari siswa. Karakteristik siswa juga dikatakan oleh responden mempengaruhi cara guru berinteraksi dengan siswa. Sedangkan responden lainnya menjelaskan bahwa pola interaksi dipengaruhi oleh situasi kelas, materi, metode serta tujuan dari pembelajaran.

Dari sulit tidaknya berinteraksi dengan siswa, 4 (empat) responden menjawab tidak pernah mengalami kesulitan interaksi dengan siswa. Sedangkan 5 (Lima) responden menjawab ada atau pernah mengalami kesulitan berinteraksi dengan siswa. 1 (satu) orang responden menjawab jarang dan satu lagi menjawab sering mengalami kesulitan.

Pada pertanyaan terakhir, yaitu pola interaksi yang memiliki pengaruh terhadap belajar serta ideal untuk siswa menurut para responden adalah banyak arah yaitu responden 1, 6, 7, 8, 9 dan dua arah menurut responden 2, 3, 5, 10, 11 sedangkan responden 4 dan 12 mengatakan pola interaksi satu arah. Hasil wawancara menunjukkan bahwa pola interaksi yang digunakan oleh guru Ekonomi Se-Kecamatan Sintang adalah pola interaksi satu arah, dua arah dan banyak arah dengan faktor penentu dalam pemilihan pola interaksi yaitu guru dan siswa, katakteristik siswa, situasi kelas, materi, metode serta tujuan dari pembelajaran. Hal ini sejalan dengan teori (Sardiman A.M., 2011) bahwa 
"Hubungan guru dengan siswa atau anak didik didalam proses belajar mengajar merupakan faktor yang sangat menentukan. Bagaimanapun baiknya bahan pelajaran yang diberikan, bagaimanapun sempurnanya metode yang digunakan, namun jika hubungan guru dan siswa yang tidak harmonis dapat menciptakan suatu hasil yang tidak di inginkan." Demikian pula pernyataan (Ratnawati, 2007) dalam hasil penelitiannya tentang Interaksi dan Proses Komunikasi dalam pembelajaran, menyatakan bahwa interaksi belajar mengajar adalah hubungan aktif antara guru yang mengajar dengan siswa yang belajar untuk mencapai tujuan instruksional yang telah ditentukan.

Hasil observasi pada pola interaksi guru dan siswa dalam pembelajaran Ekonomi berdasarkan beberapa aspek yang diamati. Adapun deskripsi hasil observasi adalah sebagai berikut:

Saat memulai pembelajaran guru menggunakan ceramah, baik sebagai pengantar untuk menyamakan persepsi siswa maupun sebagai upaya persiapan siswa dalam menerima materi selanjutnya. Setelah ceramah, selanjutnya guru melanjutkan pembelajaran dengan diskusi kelompok maupun dengan tanya jawab. Beberapa subjek penelitian memilih menggunakan metode tanya jawab di akhir penjelasan, sedangkan subjek lainnya menggunakan tanya jawab untuk selingan saat penjelasan materi.

Hasil pengamatan lainnya ditemukan hanya beberapa saja subjek penelitian yang memberikan siswa tugas berupa kasus untuk didiskusikan. Siswa terlibat aktif dalam pembelajaran sedangkan guru hanya sebagai fasilitator. Akan tetapi, dari hasil pengamatan pada subjek lainnya juga ditemukan guru hanya sebagai penceramah saja. Pertanyaan yang diajukan hanya untuk meyakinkan apakah siswa memahami penjelasan guru atau tidak. Metode yang bervariatif pun tidak ditemukan dalam proses pembelajaran sehingga dapat disimpulkan bahwa responden dominan hanya menggunakan pola interaksi satu arah. Hal ini sesuai dengan teori (W.S. Winkel, 2009) bahwa pola interaksi satu arah adalah "segala prosedur didaktis yang tercakup dalam istilah memberi ulasan, seperti menyampaikan informasi, memberikan penjelasan memberikan uraian (ceramah), menceritakan suatu kisah, mengutarakan suatu masalah dan memberikan suatu demonstrasi. Kegiatan tenaga pengajar terutama bersifat verbal, sehingga siswa harus mendengarkan, biarpun digunakan berbagai media audiovisual untuk menunjang ulasan verbal, seperti papan tulis, peta, model, gambar atau foto dan lain sebagainya. Sambil memberikan ulasannya, guru berdiri di depan siswa."

Metode seperti talking stick, Team games Tournament, problem solving dan sebagainya seperti yang seharusnya digunakan untuk meningkatkan aktivitas pembelajaran tidak ditemukan. Sedangkan hasil angket terhadap siswa jurusan IPS di 12 SMA di Kecamatan Sintang disajikan dalam grafik sebagai berikut:

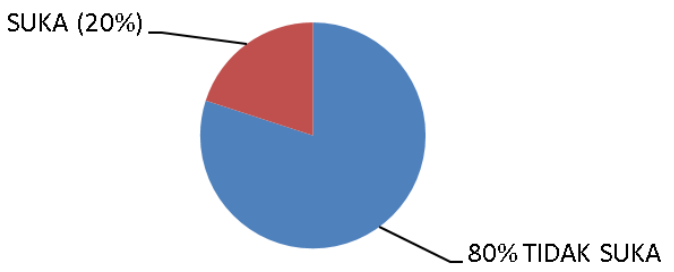

Gambar 1. Tanggapan Metode Ceramah 
Hasil angket siswa pada pola interaksi guru dan siswa dalam pembelajaran Ekonomi menunjukkan bahwa dari 120 (seratus dua puluh) responden ditemukan $80 \%$ siswa menjawab tidak menyukai pembelajaran dengan menggunakan ceramah dikarenakan suka mengantuk karena hanya mendengarkan penjelasan guru. Dengan demikian, dapat disimpulkan siswa kurang menyukai pembelajaran dengan metode satu arah.

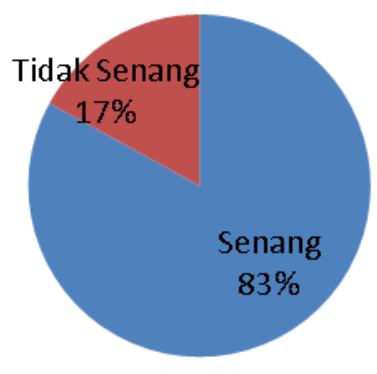

Gambar 2. Tanggapan Pola Interaksi Dua Arah

Pernyataan 3 (tiga) dan 4 (empat) yang merupakan indikator dari pola interaksi dua arah diperoleh jawaban yaitu $83 \%$ siswa merasa senang apabila diberi kesempatan bertanya oleh guru setelah guru menjelaskan materi pembelajaran. Alasan lainnya yaitu siswa merasa dapat paham dengan baik apabila guru memberi kesempatan untuk bertanya. Menjawab pernyataan 4 (empat) ditemukan $74 \%$ siswa menyatakan menyukai pembelajaran dengan adanya tanya jawab antar guru dan siswa pada saat penjelasan berlangsung.

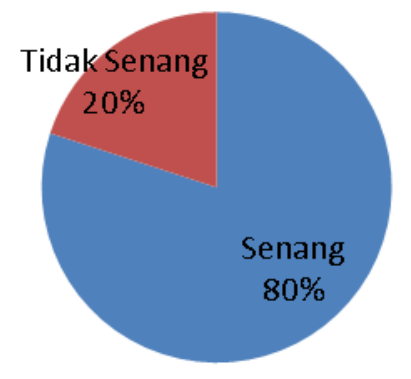

Gambar 3. Tanggapan Diskusi

Selanjutnya adalah pernyataan 5, 6, 7, 8 yang merupakan indikator dari pola interaksi tiga arah atau banyak arah. Dari hasil angket ditemukan $80 \%$ siswa menjawab senang apabila dalam pembelajaran boleh berdiskusi dengan teman, $81 \%$ siswa merasa senang apabila kurang memahami penjelasan guru, siswa boleh bertanya pada teman yang sudah paham materi tersebut, $79 \%$ siswa menyatakan senang apabila belajar dalam kelompok. Alasan yang dikemukakan adalah dapat saling membantu antar teman dalam belajar, dapat lebih berinteraksi dan dapat bertukar pendapat. Kemudian, $82 \%$ siswa menyatakan akan bertanya pada guru apabila diskusi kelompok mengalami kendala. Hal tersebut menunjukkan bahwa guru berperan sebagai fasilitator dan mediator dalam pembelajaran serta menunjukkan adanya keterkaitan semua 
aspek dalam proses pembelajaran. Siswa dapat saling berinteraksi dengan guru dan juga sesama siswa. Dengan demikian, temuan dalam penelitian ini menunjukkan keselarasan dengan hasil penelitian Julianto (2017) bahwa siswa SMA di Kecamatan Sintang mengalami kesulitan belajar dengan kategori tinggi, dimana $61,6 \%$ dipengaruhi oleh lingkungan. Adapun faktor lingkungan yang dimaksud secara spesifik adalah lingkungan sekolah yang kurang fasilitas sehingga proses pembelajaran pun tidak dapat berlangsung maksimal.

\section{SIMPULAN}

Dari hasil penelitian mengenai pola interaksi dalam proses pembelajaran ekonomi di Kecamatan Sintang, Kalimantan Barat, maka dapat disimpulkan bahwa metode pembelajaran yang biasa digunakan oleh guru Ekonomi tingkat Sekolah Menengah Atas (SMA) Se-Kecamatan Sintang adalah ceramah, tanya jawab, diskusi kelompok. Pola interaksi yang sering digunakan oleh guru Ekonomi tingkat Sekolah Menengah Atas (SMA) Se- Kecamatan Sintang adalah adalah pola interaksi satu arah, pola interaksi dua arah dan tiga arah. Faktor yang mempengaruhi pola interaksi yang dipilih oleh guru Ekonomi tersebut adalah guru dan siswa, katakteristik siswa, situasi kelas, materi, metode serta tujuan dari pembelajaran. Kemudian dari hasil angket siswa ditemukan pola interaksi yang diperlukan adalah pola interaksi banyak arah. Dengan demikian, metode pembelajaran yang bervariatif seperti talking stick, Team games Tournament, problem solving dan lainnya disarankan untuk digunakan dalam proses pembelajaran Ekonomi.

\section{DAFTAR RUJUKAN}

Akim, A. 2010. Raker Gubernur Kalbar HUT Pemda Kalbar Ke-53 Koordinasi Pemantapan Penyelenggaraan dan Pembangunan Daerah Tahun 2010. Retrieved from http://edoc.kalbarprov.go.id/berkas/DISDIK.pdf

Gerungan W.A. 2010. Psikologi Sosial. Bandung: PT Refika Aditama.

Julianto. 2017. Analisis Kesulitan Belajar Siswa Pada Mata Pelajaran Ekonomi Sekolah Menengah Atas Negeri 01 Ketungau Hulu. STKIP Persada khatulistiwa Sintang.

Miles, M. B., \& Huberman, A. M. 2007. Analisis Data Kualitatif: Buku Sumber Tentang Metode-metode Baru. Jakarta: UI Press.

Novi Irmawati. 2013. Kemampuan Guru Meningkatkan Konsentrasi Belajar Siswa Pada Mata Pelajaran Ekonomi Sekolah Menengah Atas Negeri Kelam Permai. STKIP Persada khatulistiwa Sintang.

Ratnawati, E. 2007. Interaksi dan Proses Komunikasi dalam pembelajaran. Jurnal Al-Tarbiyah, XX. 
Roza Lianti. 2016. Analisis Disiplin Belajar Siswa Dalam Proses Pembelajaran Ilmu Pengetahuan Sosial Terpadu Sekolah Menengah Pertama Sintang. STKIP Persada Khatulistiwa Sintang.

Sardiman A.M. 2011. Interaksi dan Motivasi Belajar Mengajar.

Setiadi, E. M., \& Kolip, U. 2011. Pengantar Sosiologi. Jakarta: Kencana.

Sumiati, \& Asara. 2008. Metode Pembelajaran. Bandung: CV. Wacana Prima.

W.S. Winkel. 2009. Psikologi Pengajaran. Yogyakarta: Media Abadi. 
